\title{
Associations Between Career Decision- Making Difficulties, Maladaptive Limitedness Schemas, Sleep Quality, and Circadian Preferences Among Turkish College Students
}

\author{
Murat Boysan ${ }^{1}$, Mucahit Kagan $^{2 *}$ \\ ${ }^{1}$ Department of Psychology, Faculty of Social Sciences, Yuzuncu Yil University, Van, Turkey \\ ${ }^{2}$ Department of Psychological Counseling and Guidance, Faculty of Education, Erzincan University, Erzincan, Turkey
}

\begin{abstract}
The present study investigated the relations among decision-making difficulties, maladaptive limitedness schemas, sleep quality, and circadian preferences in a sample of 311 Turkish college students. As expected, the associations between career decision-making difficulties, as measured by the Career Decision-Making Difficulties Questionnaire (CDDQ), and poor sleep quality were significant, but the connections were small. Pearson correlations of poor sleep quality with career decision-making difficulties, including Lack of Information and Difficulties related to Inconsistent Information sub-scales, and CDDQ total scores, ranged from 0.19 to 0.20 . On the other hand, in the multiple regression analyses we found that dysfunctional thinking, as measured by the Limitedness Schemas Questionnaire (LSQ), significantly contributed to all three sub-scales and total scores of the CDDQ. Implications of these findings are discussed.

Keywords: Career problem, sleep, dysfunctional thinking, career counseling, career indecision
\end{abstract}

\section{INTRODUCTION}

Career decisions are prevalent and made at different points in the life cycle. Career decision-making difficulties are integral part of the career problem which may result in a failure in career process or making decisions less than optimal (Amir \& Gati, 2006; Gati, Krausz, \& Osipow, 1996). Career decisions are also at the core of the personal identity, and thus determine the personal life style. On the basis of the literature, career decision-

*Correspondence: mkagan24agmail.com

Department of Psychological Counseling and Guidance, Faculty of Education, Erzincan University, Erzincan, Turkey

Tel: 0 (446) 22400 89/40283 Fax: 0 (0446) 2231901

\section{Sleep and Hypnosis}

Submit your manuscript at www.sleepandhypnosis.org making difficulties had significant associations with a number of psychological constructs including poor career decision-making self-efficacy (P. A. Creed \& Yin, 2006; Morgan \& Ness, 2003), occupational barriers (P. A. Creed $\&$ Yin, 2006), low androgenity (Morgan \& Ness, 2003), career indecisiveness (Albion \& Fogarty, 2002; Lancaster, Rudolph, Perkins, \& Patten, 1999; Mau, 2001), dysfunctional career thoughts (Kleiman et al., 2004), anxiety (Lancaster et al., 1999), personality traits and low emotional intelligence (Di Fabio \& Palazzeschi, 2009; Di Fabio, Palazzeschi, \& Bar-On, 2012; Di Fabio, Palazzeschi, Levin, \& Gati, 2015).

\section{Career decision-making process in counseling}

Gati et al. (1996) proposed a model of career decision-making predicated in stages of career decisionmaking, career barriers, and the effects of career 
difficulties may have been faced in the process. The taxonomy implicated three major components relevant to career decision-making difficulties: Readiness, Lack of Information, and Difficulties related to Inconsistent Information. The Career Decision-Making Difficulties Questionnaire (CDDQ) is developed to empirically test the suggested model of difficulties in making a career decision (Gati et al., 1996).

Early conceptualizations of the career decision model based on decision theory purposed a three stage intervention rationale to improve career decision-making process: Prescreening, In-depth exploration, and Choice (Gati \& Asher, 2001). Advances in career decision model placed more emphasis on career decision-making difficulties in career problem due to the fact that people with less indecisiveness problems are thought to be more benefited from career-related interventions (Amir \& Gati, 2006). In further elaboration of the decision-making based on career intervention model, locating career difficulties is one of the first stage interventions and a four stage interpretation procedure was proposed to locate the focus of client's career decision-making difficulties. These four stages of interpretation includes evaluation of 1) the credibility of a client's responses, 2) differentiation on the dimensions of career difficulties assessed by the CDDQ 3 ) categorizing the client into categories of salient, moderate or negligible career decision-making difficulties, and 4) determining the level of confidence in the feedback (Amir, Gati, \& Kleiman, 2008; Gati \& Amir, 2010). One of more recent attempts to advance the career decision-making process refined and attested a sixphase model: a) becoming more aware of career decisionmaking, b) generating alternative career choices based on one's interests, c) compromising the alternatives to a more judicious number for an in-depth exploration, d) making a career decision among alternatives, and e) confirming and commitment to the choice (Hirschi \& Laege, 2007).

\section{Career decision-making difficulties: trait or state variable}

Career indecisiveness represents pervasive, severe, and chronic problems in making career decisions. People with undecided career status had relatively stable patterns of career decision-making difficulties over a three years time period (Gati, Asulin-Peretz, \& Fisher, 2012). Germeijs, Verschueren, and Soenens (2006) asserted that, rather than a state feature, career indecisiveness should be considered as a trait factor due to the high temporal stability of the construct over a one year time period. Less confidence in one's choice and less strivings to make a career decision were tentative predictors of sustained career decision-making difficulties among college students (Saka \& Gati, 2007).

\section{Negative thinking style and career decision making difficulties}

A tendency to negative thinking has long been demonstrated to be associated with career indecisiveness in a myriad of surveillances. One third of the variance of career decision-making difficulties was explained by irrational beliefs relevant to career choice, including perfectionism, external conflict, faulty inference, generalization and self-esteem among Turkish high school students (Bacanll, 2012). In a sample of Turkish high school students, career indecisiveness was tied to negativistic appraisals in regard to career and work experience; contrarily, intrinsic satisfaction, having a sense of responsibility, persisting in the face of uncertainty, and giving a good try by working hard were inverse predictors of career indecisiveness (Akkoç, 2012). Negative career thinking was significantly associated with a sense of selfincoherence, both of these constructs significantly contributed to career indecisiveness as well as to an inclination to a general indecisiveness (Austin, Dahl, \& Wagner, 2010). Locus of control, self-esteem and irrational beliefs were differentially associated with various dimensions of personal indecisiveness that low self-esteem, external locus of control and vulnerability to irrational thinking contributed to exploratory indecisiveness while external locus of control was the only determinant of impetuous indecisiveness (Bacanli, 2006). Undergraduates who had greater goal instability reported significantly greater negative career thoughts, dissatisfaction with career choice, career tension, and low academic performance. Goal stability was suggested to be the crux of readiness in career decision-making 
(Bertoch, Lenz, Reardon, \& Peterson, 2014). Significant linkage of vocational self-concept crystallization with occupational indecisiveness was observed among college students (Landine, 2013).

Briefly speaking, there has been a vast amount of solid evidence with respect to the linkages of career decisionmaking difficulties to dysfunctional career thinking and dimensions of self-concept which have, to date, been consistently replicated in a number of studies conducted among various populations in different cultures (Gadassi, Gati, \& Wagman-Rolnick, 2013; Hamamcı \& Çoban, 2007; Jamali, Araqi, \& Kalantarkousheh, 2015; Kleiman et al., 2004; Marcionetti, 2014; Oztemel, 2014; Öztemel, 2012; Perţe, 2013; Restubog, Fiorentino, \& Garcia, 2010; Saka, Gati, \& Kelly, 2008; Sidiropoulou-Dimakakou, Mylonas, Argyropoulou, \& Tampouri, 2012).

Career indecision is a strong correlate of personal indecisiveness (Büyükgöze-Kavas, 2012). Using a structural meditational analysis approach, career decision state encompassing dissatisfaction with career choice and career indecision was directly predicted by career and life stress as well as indirectly mediated through negative career thoughts (Bullock-Yowell, Peterson, Reardon, Leierer, \& Reed, 2011). In another structural modeling study of career decision, authors reported significant relations between career decision state and neuroticism mediated through negative thinking (Bullock-Yowell et al., 2015). As such, connections of the lack of information, a component of career decision-making difficulties, was found to be directly and indirectly through negative career thoughts and feelings predicted by neuroticism personality trait (Kelly \& Shin, 2009).

\section{Gender differences}

In a representative sample of high school sample consisting of 1760 pupils, Bacanlı, Eşici, and Özünlü (2013) demonstrated that scores on Readiness, Lack of Information and Difficulties related to Inconsistent Information subscales of the CDDQ were lower in favor of girls relative to boys and higher grade girls scored significantly lower scores on these subscales in comparison to younger girls in low grades. As the socio-economical class and the importance of the career decision increased the severity of decision-making difficulties decreased. In a comparative study between United States and Turkish high school students, female students were the disadvantageous in general and students in the United States reported greater career decision-making problems relative to Turkish students (Tagay, 2014).

\section{Parental attitudes}

Regarding parental attitudes, high school students whose parents were more authoritative or authoritarian were determined in their career path in comparison to youths with neglectful and indulgent parents. The relationship between parental attachment and decisiveness was curvilinear rather than linear (CenksevenOnder, Kirdok, \& Isik, 2010). Perceived parental expectations and perceived self-performance as well as cultural value conflicts exacerbated the career decisionmaking difficulties among Chinese college students (Leung, Hou, Gati, \& Li, 2011). Contrarily, parental attitudes could not be found to be associated with career decision difficulties; whereas personal/social guidance needs, educational guidance needs and career guidance needs indicated greater career decision-making problems (Kesici, Hamarta, \& Arslan, 2008). Perceived social support from teachers was reported to be a significant antecedent of reported difficulties regarding career decision-making among Turkish 9 to 11 grades (Öztemel, 2013).

\section{Personality-related trait features and career making problems}

Personal residency was predictive of alleviated career decision-making difficulties through facilitating overcoming the problems during the process. On the contrary, procrastination was the most unproductive strategy in response to career problems that undermines and delays making a decision to use personal sources in taking an action (Shin \& Kelly, 2015). Perceived control on career decision alleviated career indecision and career anxiety students. Pupils in professional faculties reported less career-related problems compared to counterparts probably due to a sense of control on their career (Daniels, Stewart, Stupnisky, Perry, \& LoVerso, 2011). 
Similar findings in regard to students enrolled in faculty of education were reported in Turkey (Akgün \& Karaca, 2012).

From the point of an attachment view, anxious attachment significantly indirectly contributed to career indecision in which the associations were fully mediated by career choice anxiety and career-choice pessimism (Braunstein-Bercovitz, Benjamin, Asor, \& Lev, 2012).

Emotional and personality-related career decisionmaking difficulties were significant correlates of low selfesteem, exploratory and impetuous indecisiveness, and neuroticism. Consciousness and extraversion were negative correlates of career decision-making difficulties (Oztemel, 2014). Career decision-making difficulties were tied to greater external locus of control, neuroticism, agreeableness, perfectionism and need for cognitive closure, and decreased career decision self-efficacy, extraversion, and openness to experience (Gati et al., 2011). In a meta-analysis of 20 studies with respect to the relations between five-factor model personality traits and career decision-making difficulties, Martincin and Stead (2015) concluded that neuroticism was the prominent determinant of career decision problems contrarily Agreeableness, Conscientiousness, Extraversion, and Openness to experience personality traits were inverse correlates of career indecisiveness.

\section{Career decision-making difficulties and well-being}

In recent years, scholars have underscored a need to a holistic approach in which career counseling needs and mental health interventions are combined together (Blustein, 2008; Lenz, Peterson, Reardon, \& Saunders, 2010). According to cognitive information processing approach, solving career problems through career counselling refers to helping clients progress along a continuum from a state of an existing state of indecision which may entail confusion, anxiety, depression, and an external locus of control toward a more desired state (Peterson, Sampson Jr, Lenz, \& Reardon, 2002).

Research has shown that life and job satisfaction are significantly connected with each other (A. Doğan, Deniz, Odabas, Özyeşil, \& Özgirgin, 2012; Yeşilyaprak \& Boysan, 2015). More specifically, life satisfaction is associated with self-esteem in relation to decision-making and decisionmaking styles (Deniz, 2004, 2006). Empirical evidence has consistently provided support with the significant relations between career decision-making difficulties and depressive symptoms. University students who made a career decision were less depressive than pupils who were undecided (Rottinghaus, Jenkins, \& Jantzer, 2009). Self-concept and identity-related career decision-making difficulties were predictive of depressive symptomatology. Specifically for men, but not among women, crystallization of career preferences was preventive from depressive symptoms (Gadassi, Waser, \& Gati, 2015). Career indecision and dysfunctional career thoughts significantly contributed to depressive symptomatology (Walker \& Peterson, 2012).

\section{Current study}

Career decisiveness has monumental importance of well-being and social achievement that those youths who were decided in their career path prospectively reported higher levels of career maturity, greater career decisionmaking efficiency, higher self-esteem, less career indecision, and attenuated levels of panic compared to undecided respondents (P. Creed, Prideaux, \& Patton, 2005). Moreover, it has been well-established that majority of people are seeking help from guidance and counseling services in dealing with career problems particularly career indecision and career difficulties in Turkey (Bacanlı et al., 2013; Çakır, 2004; H. Doğan \& Bacanli, 2012; Oztemel, 2013). Therefore assessment of career difficulties has of monumental importance to finetune career counseling interventions. Different from other screening tools with regards to career problems, the CDDQ reflects an extensive refinement of theoretical considerations encapsulating the complex pattern of career difficulties (Bacanl, 2015; Gati \& Saka, 2001a, 2001b).

Given the previous depression literature there has been a vast body of research documenting the significant relations between depressive symptomatology and sleep problems (Gulec et al., 2011; Selvi et al., 2010). Although the significant linkages of career decision-making difficulties and dysfunctional thinking patterns related to 
career problems to depressive symptomatology have been well-established, tentative associations with sleep and circadian preferences have received no attention so far.

Circadian preferences inform a tendency for an individual to work, to sleep and active in functioning at particular times during a 24-hour period. Circadian preferences are conceptualized as a physiological construct along a continuum with two extremes: eveningness and morningness (Natale \& Cicogna, 2002; Tonetti, 2007). Individuals with eveningness circadian preference had substantially shorter sleep duration during weekdays and more sleep disturbances in comparison to individuals with morningness preferences (Harada, Morikuni, Yoshii, Yamashita, \& Takeuchi, 2002; Taillard, Philip, \& Bioulac, 1999; Tavernier \& Willoughby, 2014; Tzischinsky \& Shochat, 2011). Individuals with eveningness diurnal preferences are more vulnerable to depression (Kim et al., 2010; Merikanto et al., 2013; Muller, Kundermann, \& Cabanel, 2016).

In one of preliminary surveillances of connections between decision-making styles and circadian preferences, Tonetti et al. (2016) observed that eveningness significantly contributed to avoidant and spontaneous decision-making styles. In a more previous study, it was found low morningness was significantly associated with avoidant procrastination (Diaz-Morales, Ferrari, \& Cohen, 2008). Additionally, sleep deprivation causes severe impairment in decision-making (Harrison \& Horne, 2000; Killgore, Balkin, \& Wesensten, 2006). Given the previous evidence, there has been a lack of interest in relations between sleep and career problems. In this study, we aimed to investigate the connections of sleep quality, circadian preferences, dysfunctional thinking patterns in terms of limitedness schemas questionnaire with career decision-making difficulties.

\section{METHOD}

\section{Participants and procedure}

Three hundred eleven undergraduates enrolled in various programs at Erzincan University participated in the study. A set of psychometric measures including the
Limitedness Schemas Questionnaire, Career DecisionMaking Difficulties Questionnaire, MorningnessEveningness Questionnaire, and Pittsburgh Sleep Quality Index along with a socio-demographic questionnaire was administered by researchers on only one occasion on to the participants. A brief description of the study was made and written consent was taken prior to the scale was administered. After providing the participants with information about the study and receiving written consent, survey form was administered to respondents. One hundred seventy participants were females (54.66\%). Age was ranging from 17 to 25 , and the mean age of the sample was 20.10 ( $S D \pm 1.75)$.

\section{Psychometric measures}

\section{Career Decision-Making Difficulties Questionnaire (CDDQ)}

The 34-item Career Decision-Making Difficulties Questionnaire (CDDQ) a shortened version derived from the 44-item long form, was administered to participants (Gati \& Saka, 2001a). Each item is rated on a 9-point Likert scale ( $1=$ does not describe me, and 9=describes me well). Two items of the scale is for validity check and the remained 32 items measures career difficulties in ten categories subsumed in three supreme categories representing stages of career counseling in relation to making career decisions. Three second-order factors include readiness (lack of motivation, general indecisiveness, and dysfunctional beliefs), lack of information (about the stages of career decision-making process, self, occupations, and ways of obtaining additional information), and inconsistent Information (unreliable information, internal conflicts, and external conflicts). It was reported adequate internal reliability for the CDDQ ( $a=0.91$ for the overall scale, $a=0.63$ for lack of readiness, $a=0.88$ for lack of information and $a=0.87$ for inconsistent information). Turkish version of the CDDQ was demonstrated to have adequate psychometric properties by Bacanlı (2015). The Lack of Information, Inconsistent Information, Lack of Readiness sub-scales had internal consistency of $a=0.90, a=0.84$, and $a=0.45$, respectively (Bacanl, 2015).

The construct, convergent and divergent validity of 
paper-pencil and internet versions of the scale have extensively studied in various psychometric studies and generally it has been reported good psychometric properties for the CDDQ (Albion \& Fogarty, 2002; Bacanlı et al., 2013; Gati \& Saka, 2001a, 2001b; Kelly \& Lee, 2002; Kleiman \& Gati, 2004; Kleiman et al., 2004; Lancaster et al., 1999; Mau, 2001; Morgan \& Ness, 2003; Tien, 2005) to be interpreted as the concept of career difficulties is a multidimensional psychological construct in nature. Three factor structure for the CDDQ have been generally confirmed (Bacanlı, 2015; Gati \& Saka, 2001a; Kleiman et al., 2004) and only several studies suggested a different factor structure for the screening tool (Albion \& Fogarty, 2002; P. A. Creed \& Yin, 2006). However, most of the psychometric investigations of the CDDQ reported fairly low internal consistency less than 0.70 for the subscales of lack of readiness main component (Bacanl, 2015; Gati \& Saka, 2001a, 2001b; Lancaster et al., 1999; Leung et al., 2011; Mau, 2001; Osipow \& Gati, 1998; Tien, 2005; Zhou \& Santos, 2007). Also lack of readiness subscales had low convergent validity in relation to associated variables (Kleiman et al., 2004; Lancaster et al., 1999; Mau, 2001).

\section{Limitedness Schemas Questionnaire (LSQ)}

A 30-item self-report scale designed to assess dysfunctional thinking patterns encompassing limitedness about the world, negativistic expectations about interpersonal relations, stability of these negativistic attributions, and interconnectedness of events. The scale had good reliability with a internal consistency of 0.89 and validity with significant correlations with depression, anxiety, learned helplessness and low self-esteem (Boysan, Besiroglu, Kara, Kayri, \& Keskin, 2008).

\section{Morningness-Eveningness Questionnaire (MEQ)}

The MEQ consists of 19 self-report items designed to assess individual differences in chronobiology (Horne \& Ostberg, 1976). Preferences in sleep and rise times, and the degree to which respondents are active and alert at certain times of day are assessed. The scale is the most widely used screening tool in evaluation of diurnal preferences. Turkish version of the scale had good validity and reliability (Agargun, Cilli, Boysan, \& Selvi, 2007).

\section{Pittsburgh Sleep Quality Index (PSQI)}

A 19-item self-report questionnaire designed to assess sleep quality and disturbances over a one month time interval (Buysse, Reynolds, Monk, Berman, \& Kupfer, 1989). The PSQl yields a score ranging between 0 and 21. The Turkish version of the psychometric tool was demonstrated to have good reliability and validity (Ağargün, Kara, \& Anlar, 1996).

\section{Statistical Analysis}

Initially, we computed sample descriptive statistics. We run zero-order correlation analyses. Then, we run four multiple regression analyses in which subscale and total scores of the CDDQ were dependent variables. The significance threshold was held at $p<0.05$.

\section{RESULTS}

\section{Correlation analyses between psychological variables}

We run Pearson product-moments correlation coefficients between psychological variables. Considering bivariate relations, sleep quality was significantly associated with Lack of Information $(r=0.19 p<0.01)$ and Difficulties related to Inconsistent Information $(r=0.19$ $p<0.01)$ sub-scales, and overall scores of the CDDQ $(r=0.20 p<0.01)$. Eveningness circadian preferences was weakly correlated with Difficulties related to Inconsistent Information $(r=-0.13 p<0.05)$. Means, standard deviations and correlation coefficients are presented in Table 1.

\section{Multiple regression analyses}

We run four multiple stepwise regression analyses, in which subscales and overall scores of the CDDQ were dependent variables. In the regression models age, gender, income, paternal education, maternal education, the Limitedness Schemas Questionnaire, MorningnessEveningness Questionnaire scores and Pittsburgh Sleep Quality Index were predictors.

In the first regression analysis, independent variables were regressed onto the Career Decision Making 
Table 1. Pearson product-moments correlation coefficients

\begin{tabular}{|c|c|c|c|c|c|c|c|c|}
\hline & & 1 & 2 & 3 & 4 & 5 & 6 & 7 \\
\hline \multirow[t]{2}{*}{ 1. Readiness } & r & 1 & & & & & & \\
\hline & $\mathrm{N}$ & 311 & & & & & & \\
\hline \multirow[t]{2}{*}{ 2. Lack of Information about } & r & $0.288^{* *}$ & 1 & & & & & \\
\hline & $\mathrm{N}$ & 311 & 311 & & & & & \\
\hline \multirow[t]{2}{*}{ 3. Difficulties related to Inconsistent Information } & r & $0.302^{* *}$ & $0.739 * *$ & 1 & & & & \\
\hline & $\mathrm{N}$ & 311 & 311 & 311 & & & & \\
\hline \multirow[t]{2}{*}{ 4. Career Decision Making Difficulties Questionnaire } & $r$ & $0.595^{\star \star}$ & $0.894 * *$ & $0.878 * \star$ & 1 & & & \\
\hline & $\mathrm{N}$ & 311 & 311 & 311 & 311 & & & \\
\hline \multirow[t]{2}{*}{ 5. Limitedness Schemas Questionnaire } & r & $0.225^{\star *}$ & $0.276^{\star *}$ & $0.319 * *$ & $0.342^{* *}$ & 1 & & \\
\hline & $\mathrm{N}$ & 311 & 311 & 311 & 311 & 311 & & \\
\hline \multirow{2}{*}{ 6. Morningness-Eveningness Questionnaire } & r & -0.014 & -0.049 & $-0.132^{*}$ & -0.084 & $-0.312^{\star *}$ & 1 & \\
\hline & $\mathrm{N}$ & 311 & 311 & 311 & 311 & 311 & 311 & \\
\hline \multirow[t]{2}{*}{ 7. Pittsburgh Sleep Quality Index } & r & 0.112 & $0.185^{\star \star}$ & $0.188^{* *}$ & $0.204^{* *}$ & $0.334 * *$ & $-0.258^{* *}$ & 1 \\
\hline & $\mathrm{N}$ & 288 & 288 & 288 & 288 & 288 & 288 & 288 \\
\hline Mean & & 4.64 & 3.18 & 3.19 & 3.64 & 50.12 & 52.48 & 7.17 \\
\hline Standard Deviation & & 1.33 & 1.68 & 1.68 & 1.27 & 21.32 & 8.07 & 2.02 \\
\hline
\end{tabular}

Note. ${ }^{*}: p<0.05 ; * *: p<0.01$

Table 2. Regression analysis of Career Decision-Making Difficulties Questionnaire total scores

\begin{tabular}{|c|c|c|c|c|c|c|c|c|}
\hline & $\mathbf{R}^{2}$ & B & S.E. & ß & $\mathbf{t}$ & $\mathbf{P}$ & Tolerance & VIF \\
\hline & 0.140 & & & & & & & \\
\hline Age & & -0.032 & 0.044 & -0.042 & -0.724 & 0.470 & 0.897 & 1.115 \\
\hline Gender & & -0.144 & 0.151 & -0.056 & -0.952 & 0.342 & 0.891 & 1.123 \\
\hline Income & & -0.109 & 0.154 & -0.041 & -0.708 & 0.479 & 0.916 & 1.092 \\
\hline Paternal Education & & 0.084 & 0.072 & 0.072 & 1.165 & 0.245 & 0.803 & 1.246 \\
\hline Maternal Education & & -0.083 & 0.110 & -0.047 & -0.755 & 0.451 & 0.809 & 1.236 \\
\hline Limitedness Schemas Questionnaire & & 0.019 & 0.004 & 0.313 & 4.966 & $<0.001$ & 0.775 & 1.290 \\
\hline Morningness-Eveningness Questionnaire & & 0.006 & 0.010 & 0.039 & 0.641 & 0.522 & 0.824 & 1.214 \\
\hline Pittsburgh Sleep Quality Index & & 0.074 & 0.038 & 0.117 & 1.924 & 0.055 & 0.838 & 1.194 \\
\hline
\end{tabular}

Note. B= Unstandardized regression coefficient; S.E.= Standard Error; $\beta=$ Standardized regression coefficient; VIF= Variance inflation factor; significant statistics are boldfaced.

Difficulties Questionnaire total scores. The regression model explained $14 \%$ of the variance of dependent variable. Model $F$ value was significant $(F(8,279)=5.655$ $p<0.01)$. Of the predictors, only dysfunctional limited schemas significantly contributed to Career Decision Making Difficulties Questionnaire total scores ( $\beta=0.31$ $\mathrm{t}=4.966 p<0.001$ ). Results are given in Table 2 and partial regression plot was indicated in Figure 1.

In the second regression analysis, independent variables were regressed onto Readiness sub-scale scores. The regression model explained $7 \%$ of the variance of dependent variable. Model $F$ value was significant $(F(8$, $279)=2.493 p<0.05)$. According to results, only dysfunctional limited schemas significantly contributed to Readiness scores $(\beta=0.24 t=3.674 p<0.001)$. Results are presented in Table 3 and partial regression plot was indicated in Figure 2.

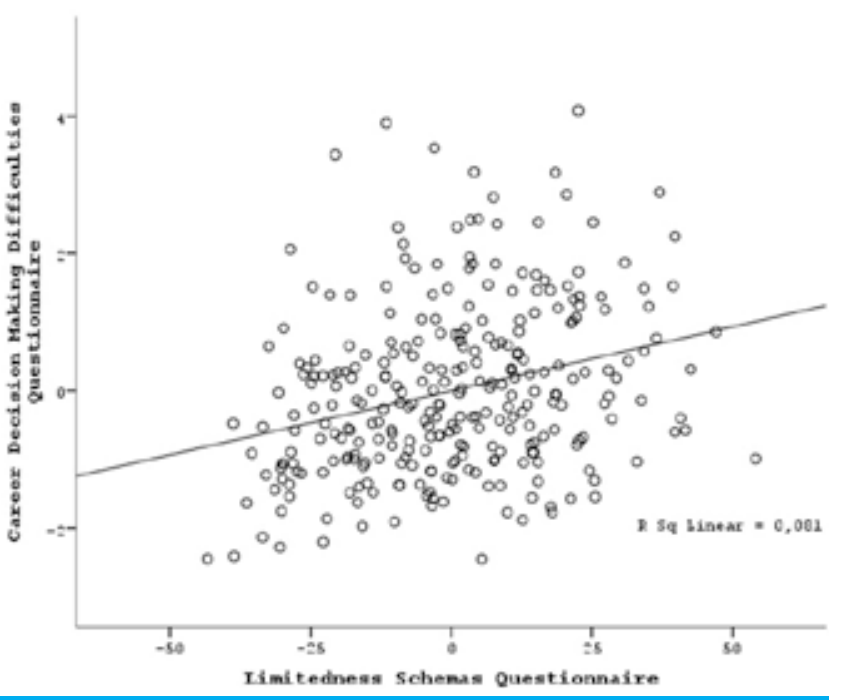

Figure 1: The partial plot for the regression of the Limitedness Schemas Questionnaire scores onto the Career Decision-Making Difficulties Questionnaire (CDDQ) total scores. 
In the third regression analysis, independent variables were regressed onto Lack of Information sub-scale scores. The regression model explained $10 \%$ of the variance of dependent variable. Model F value was significant $(F(8$, $279)=3.784 p<0.001)$. Results indicated that only dysfunctional limited schemas significantly contributed to Lack of Information sub-scale scores $(\beta=0.24 \mathrm{t}=3.759$ $p<0.001)$. Results are presented in Table 4 and partial regression plot was indicated in Figure 3.

In the final regression analysis, independent variables

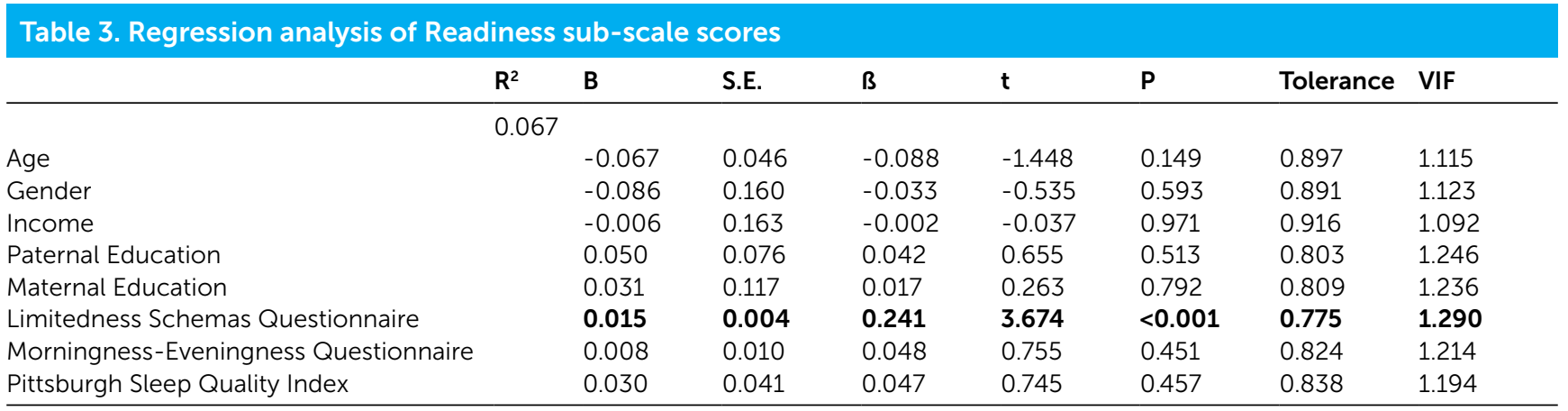

Note. B = Unstandardized regression coefficient; S.E.= Standard Error; $ß=$ Standardized regression coefficient; VIF= Variance inflation factor; significant statistics are boldfaced.

\section{Table 4. Regression analysis of Lack of Information sub-scale scores}

\begin{tabular}{|c|c|c|c|c|c|c|c|c|}
\hline & $\mathbf{R}^{2}$ & B & S.E. & B & $\mathbf{t}$ & $\mathbf{P}$ & Tolerance & VIF \\
\hline & 0.09 & & & & & & & \\
\hline Age & & -0.028 & 0.059 & -0.029 & -0.480 & 0.631 & 0.897 & 1.115 \\
\hline Gender & & -0.097 & 0.203 & -0.029 & -0.479 & 0.632 & 0.891 & 1.123 \\
\hline Income & & -0.129 & 0.207 & -0.037 & -0.626 & 0.532 & 0.916 & 1.092 \\
\hline Paternal Education & & 0.090 & 0.097 & 0.059 & 0.933 & 0.351 & 0.803 & 1.246 \\
\hline Maternal Education & & -0.197 & 0.148 & -0.084 & -1.333 & 0.184 & 0.809 & 1.236 \\
\hline Limitedness Schemas Questionnaire & & 0.019 & 0.005 & 0.243 & 3.759 & $<0.001$ & 0.775 & 1.290 \\
\hline Morningness-Eveningness Questionnaire & & 0.012 & 0.013 & 0.055 & 0.877 & 0.381 & 0.824 & 1.214 \\
\hline Pittsburgh Sleep Quality Index & & 0.101 & 0.052 & 0.122 & 1.960 & 0.051 & 0.838 & 1.194 \\
\hline
\end{tabular}

Note. B= Unstandardized regression coefficient; S.E.= Standard Error; $B=$ Standardized regression coefficient; VIF= Variance inflation factor; significant statistics are boldfaced.

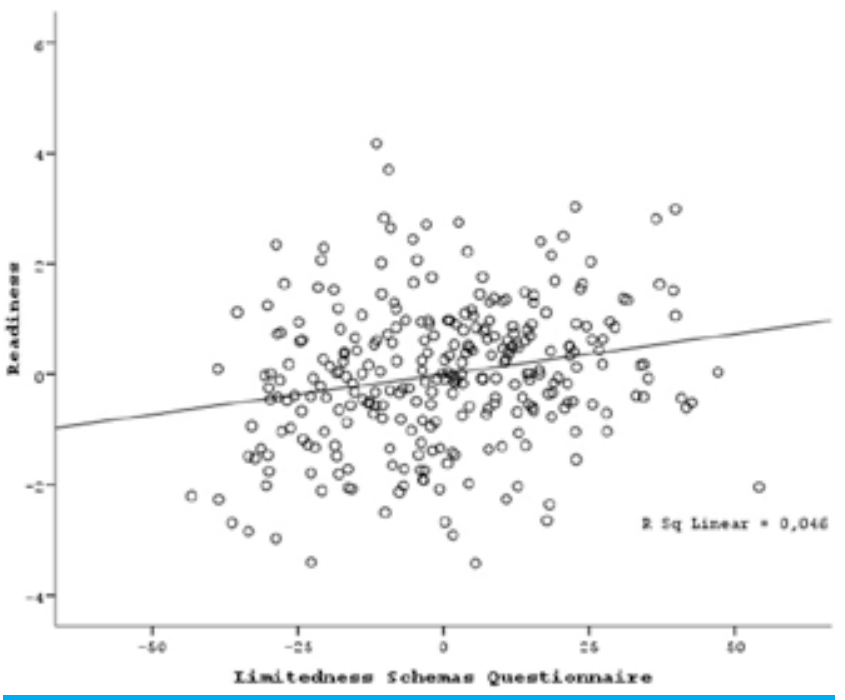

Figure 2: The partial plot for the regression of the Limitedness Schemas Questionnaire scores onto Readiness subscale of the CDDQ scores.

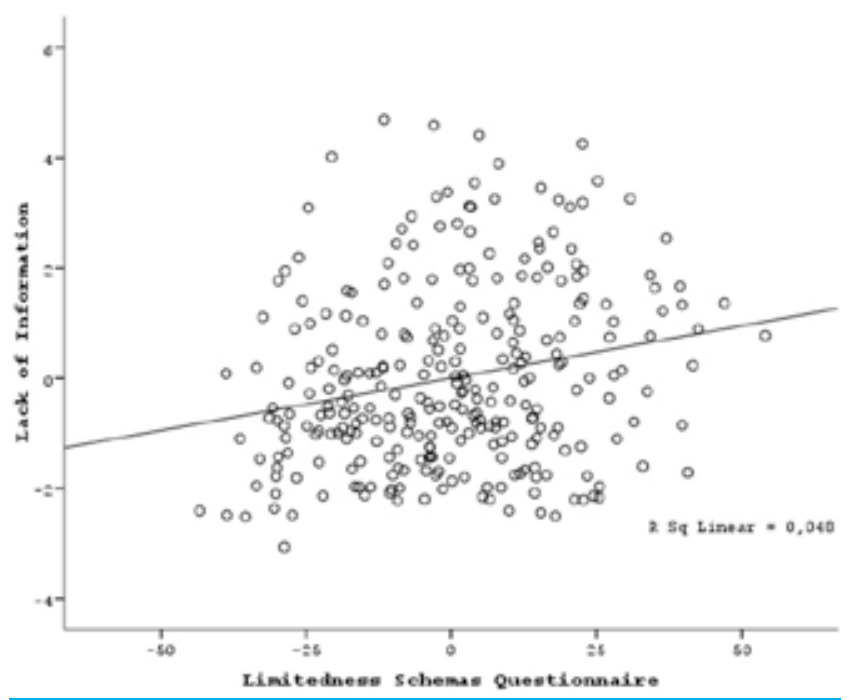

Figure 3: The partial plot for the regression of the Limitedness Schemas Questionnaire scores onto Lack of Information subscale of the CDDQ scores. 
Table 5. Regression analysis of Difficulties related to Inconsistent Information sub-scale scores

\begin{tabular}{|c|c|c|c|c|c|c|c|c|}
\hline & $\mathbf{R}^{2}$ & B & S.E. & B & $\mathbf{t}$ & $\mathbf{P}$ & Tolerance & VIF \\
\hline & 0.12 & & & & & & & \\
\hline Age & & 0.000 & 0.058 & 0.000 & -0.007 & 0.994 & 0.897 & 1.115 \\
\hline Gender & & -0.258 & 0.201 & -0.076 & -1.287 & 0.199 & 0.891 & 1.123 \\
\hline Income & & -0.187 & 0.204 & -0.054 & -0.917 & 0.360 & 0.916 & 1.092 \\
\hline Paternal Education & & 0.110 & 0.095 & 0.072 & 1.153 & 0.250 & 0.803 & 1.246 \\
\hline Maternal Education & & -0.060 & 0.146 & -0.025 & -0.410 & 0.682 & 0.809 & 1.236 \\
\hline Limitedness Schemas Questionnaire & & 0.022 & 0.005 & 0.284 & 4.471 & $<0.001$ & 0.775 & 1.290 \\
\hline Morningness-Eveningness Questionnaire & & -0.002 & 0.013 & -0.008 & -0.123 & 0.902 & 0.824 & 1.214 \\
\hline Pittsburgh Sleep Quality Index & & 0.085 & 0.051 & 0.101 & 1.661 & 0.098 & 0.838 & 1.194 \\
\hline
\end{tabular}

Note. $B=$ Unstandardized regression coefficient; S.E.= Standard Error; $ß=$ Standardized regression coefficient; VIF= Variance inflation factor; significant statistics are boldfaced

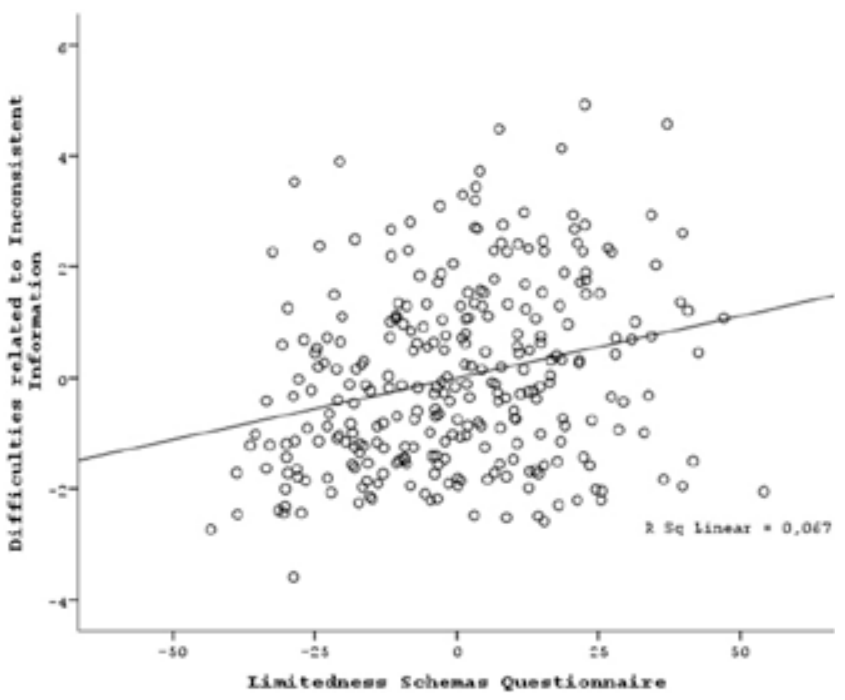

Figure 4: The partial plot for the regression of the Limitedness Schemas Questionnaire scores onto Difficulties related to Inconsistent Information subscale of the CDDQ scores.

were regressed onto Difficulties related to Inconsistent Information sub-scale scores. The regression model explained $13 \%$ of the variance of dependent variable. Model $F$ value was significant $(F(8,279)=5.137 p<0.01)$. Results indicated that only dysfunctional limited schemas significantly contributed to Difficulties related to Inconsistent Information sub-scale scores $(\beta=0.28 \mathrm{t}=4.471$ $p<0.001)$. Results are presented in Table 5 and partial regression plot was indicated in Figure 4.

\section{DISCUSSION}

The aim of the current study was to investigate the relations between career decision-making difficulties measured by the 34-item the Career Decision Making Difficulties Questionnaire (CDDQ; Gati \& Saka, 2001a), dysfunctional limitedness schemas, sleep quality and circadian preferences on the data collected from Turkish college students. We carried out zero-order correlational analyses to unpack the relations between variables that poor sleep quality indicated greater levels of Lack of Information, Difficulties related to Inconsistent Information, and Career Decision Making Difficulties Questionnaire total scores. Additionally, dysfunctional limitedness schemas were significantly associated with subscale and total scores of the CDDQ scores. In the regression analyses, it was found that only dysfunctional thinking was predictive of career decision-making difficulties.

Research has consistently found people at an earlier age have greater career difficulties than older people (Gati et al., 1996; Morgan \& Ness, 2003; Sovet, Tak, \& Jung, 2015; Tien, 2005). This may be due to the less experience in career decision making and career-related practices including education and work. Associations between gender and career-decision making difficulties have revealed a pattern of inconsistencies. Some of studies reported unsubstantial differences in careerdecision making difficulties between genders (Gati, Osipow, Krausz, \& Saka, 2000; Koumoundourou, Tsaousis, \& Kounenou, 2011; Osipow \& Gati, 1998). Bacanlı et al. (2013) observed a significant interaction between gender and grade among 1760 high school students that girls from upper grades had significantly lower career difficulties relative to boys from lower grades. In a crosscultural investigation of career decision making difficulties, 
British female undergraduates had significantly greater career difficulties on three main domains and total scores than British males; whereas no significant gender difference was detected among Chinese participants (Zhou \& Santos, 2007). Among Turkish undergraduates, interaction effect between grade and gender was not significant whether gender per se had a significant main effect (Bacanl, 2015). We could not find any gender and age differences in total and subscales scores of the Career Decision-Making Questionnaire.

Consistent with the previous literature (Gadassi et al., 2013; Hamamcı \& Çoban, 2007; Jamali et al., 2015; Kleiman et al., 2004; Marcionetti, 2014; Oztemel, 2014; Öztemel, 2012; Perţe, 2013; Restubog et al., 2010; Saka et al., 2008; Sidiropoulou-Dimakakou et al., 2012), we found that dysfunctional thinking was the most potent predictor of career decision-making problems. In this study, rather than career-related dysfunctional thinking, we utilized a more general conceptualization of sense of limitedness with respect to dysfunctional thinking patterns. In the literature it has been demonstrated that limitedness schemas has significant associations with a myriad of vulnerability factors and negative psychological outcomes including maladaptive perfectionism (Kağan, 2011), and depression (Kayri \& Boysan, 2008). In this study, facets of career decision problems were significantly associated with limitedness schemas. Moreover, sleep problems were accompanying to career related decision-making difficulties, a preliminary finding of this study.

This study has several limitations. First of all this study was conducted in a relatively small group of college students. Finding should be replicated in larger samples including observations in younger and adult respondents with respect to the variables addressed here. Second, a cross-section design was adopted in this study. In a

\section{References}

Agargun, M. Y., Cilli, A. S., Boysan, M., \& Selvi, Y. (2007). Turkish version of Morningness-Eveningness Questionnaire (MEQ). Sleep and Hypnosis, 9(1), 16-23.

Ağargün, M. Y., Kara, H., \& Anlar, Ö. (1996). The validity and reliability of the Pittsburgh Sleep Quality Index. Turkish Journal of Psychiatry, 7(2), 107-115. longitudinal design study, findings could have differentiated from the current results.

Career counseling is a dynamic applied field with many facets in practice (Yeşilyaprak, 2012). Career indecisiveness is a significant component of career problem that should be taken into consideration during career interventions. Our findings should be interpreted along with Bacanlı (2015) that the Turkish version of the CDDQ may be utilized in a thorough assessment of categories of career difficulties among high school students and undergraduates. The CDDQ provides an opportunity to easily screen community sample for identification of groups of students who have career problems and counseling needs. The screening tool makes it possible to follow-up outcomes of career interventions. Furthermore, there have been several attempts to develop more influential interventions in regard to career decision-making difficulties in the literature (Amir, Gati \& Kleiman, 2008; Gati \&Amir, 2010; Gati \& Asher, 2001; Hirschi \& Laege, 2007). Although there has been a large consensus on the fact that career counselling and metal health related interventions should be used in combination (e.g., Lenz et al., 2010), all of these interventions mentioned above have a central focus on decision making process. Drawing from the current findings, to the best of our experience, integrating therapeutic techniques gleaned from cognitivebehavioral therapies would be beneficial (Beck \& Beck, 2011). Affect regulation training (Berking \& Whitley, 2014; Linehan, 2014) incorporated with sleep-related interventions (Perlis, Jungquist, Smith, \& Posner, 2008; Sateia \& Buysse, 2010) would provide more promising outcomes in career counseling. The earlier ages these career interventions are applied, the more positive outcomes would be achieved (Nazli, 2007).

Akgün, Ö. E., \& Karaca, O. (2012). Bilgisayar ve öğretim teknolojileri eğitimi (böte) öğrencilerinin mesleki karar verme zorluklarının incelenmesi. Paper presented at the VI. Ulusal Lisansüstü Eğitim Sempozyumu.

Akkoç, F. (2012). The relationship between the vocational indecision and career beliefs of high school students. Buca Eğitim Fakültesi Dergisi, 32, 49-70. 
Boysan / Sleep and Hypnosis 2016;18(4):97-110

Albion, M. J., \& Fogarty, G. J. (2002). Factors influencing career decision making in adolescents and adults. Journal of Career Assessment, 10(1), 91-126. doi: Doi 10.1177/1069072702010001006

Amir, T., \& Gati, I. (2006). Facets of career decision-making difficulties. British Journal of Guidance \& Counselling, 34(4), 483503. doi: $10.1080 / 03069880600942608$

Amir, T., Gati, I., \& Kleiman, T. (2008). Understanding and interpreting career decision-making difficulties. Journal of Career Assessment, 16(3), 281-309. doi: 10.1177/1069072708317367

Austin, R. K., Dahl, A. D., \& Wagner, B. D. (2010). The roles of negative career thoughts and sense of coherence in predicting career decision status. Canadian Journal of Counselling and Psychotherapy, 44(1), 65-77.

Bacanli, F. (2006). Personality characteristics as predictors of personal indecisiveness. Journal of Career Development, 32(4), 320-332. doi: 10.1177/0894845305282941

Bacanl, F. (2012). Relationships between career decision making difficulties and irrational beliefs about career choice. Turkish Psychological Counseling and Guidance Journal, 4(37), 86-95.

Bacanlı, F. (2015). Career decision-making difficulties of Turkish adolescents. International Journal of Educational and Vocational Guidance, 1-18. doi: 10.1007/s10775-015-9304-8

Bacanlı, F., Eşici, H., \& Özünlü, B. M. (2013). An examination of career decision-making difficulties according to several variables. Turkish Psychological Counseling and Guidance Journal, 5(40), 198-211.

Beck, J. S., \& Beck, A. T. (2011). Cognitive behavior therapy : basics and beyond (S. Edition Ed.). New York, NY: Guilford.

Berking, M., \& Whitley, B. (2014). Affect regulation training: A practitioners' manual. New York, NY: Springer

Bertoch, S. C., Lenz, J. G., Reardon, R. C., \& Peterson, G. W. (2014). Goal Instability in Relation to Career Thoughts, Decision State, and Performance in a Career Course. Journal of Career Development, 41(2), 104-121. doi: 10.1177/0894845313482521

Blustein, D. L. (2008). The role of work in psychological health and well-being - A conceptual, historical, and public policy perspective. American Psychologist, 63(4), 228-240. doi: 10.1037/0003-066X.63.4.228

Boysan, M., Besiroglu, L., Kara, H., Kayri, M., \& Keskin, S. (2008). Associations between the levels of depression and the sense of limitedness: a psychometric analysis. Anadolu Psikiyatri DergisiAnatolian Journal of Psychiatry, 9(4), 191-196.

Braunstein-Bercovitz, H., Benjamin, B. A., Asor, S., \& Lev, M. (2012). Insecure attachment and career indecision: Mediating effects of anxiety and pessimism. Journal of Vocational Behavior, 81(2), 236-244. doi: 10.1016/j.jvb.2012.07.009

Bullock-Yowell, E., Peterson, G. W., Reardon, R. C., Leierer, S. J., \& Reed, C. A. (2011). Relationships among career and life stress, negative career thoughts, and career decision state: A cognitive information processing perspective. Career Development Quarterly, 59(4), 302-314. doi: 10.1002/j.2161-0045.2011.tb00071.x Bullock-Yowell, E., Reed, C. A., Mohn, R. S., Galles, J., Peterson, G. W., \& Reardon, R. C. (2015). Neuroticism, negative thinking, and coping with respect to career decision state. Career Development Quarterly, 63(4), 333-347. doi: 10.1002/cdq.12032

Buysse, D. J., Reynolds, C. F., Monk, T. H., Berman, S. R., \& Kupfer, D. J. (1989). The Pittsburgh Sleep Quality Index - a New Instrument for Psychiatric Practice and Research. Psychiatry Research, 28(2), 193-213. doi: 10.1016/0165-1781(89)90047-4
Büyükgöze-Kavas, A. (2012). Turkish adaptation of career decision scale: Validity and reliability study. Turkish Psychological Counseling and Guidance Journal, 4(38), 159-168.

Cenkseven-Onder, F., Kirdok, O., \& Isik, E. (2010). High school students career decision-making pattern across parenting styles and parental attachment levels. Electronic Journal of Research in Educational Psychology, 8(1), 263-280.

Creed, P. A. , \& Yin, W. O. (2006). Reliability and validity of a Chinese version of the Career Decision-Making Difficulties Questionnaire. International Journal for Educational and Vocational Guidance, 6(1) 47-63. doi: 10.1007/s10775-006-0003-3

Creed, P., Prideaux, L. A., \& Patton, W. (2005). Antecedents and consequences of career decisional states in adolescence. Journal of Vocational Behavior, 67(3), 397-412. doi: 10.1016/j.jvb.2004.08.008

Çakır, M. A. (2004). The development of the Career Decision Inventory. Ankara University Journal of Faculty of Educational Sciences, 37(2), 1-14.

Daniels, L. M., Stewart, T. L., Stupnisky, R. H., Perry, R. P., \& LoVerso, T. (2011). Relieving career anxiety and indecision: the role of undergraduate students' perceived control and faculty affiliations. Social Psychology of Education, 14(3), 409-426. doi: 10.1007/ s11218-010-9151-x

Deniz, M. E. (2004). Investigation of the relation between decision making, self-esteem, decision making style and problem solving skills of university students. Eurasian Journal of Educational Research, 4(15), 23-35.

Deniz, M. E. (2006). The relationships among coping with stress, life satisfaction, decision making styles and decision self-esteem: An investigation on Turkish university students. Social Behavior and Personality, 34(9), 1161-1170. doi: 10.2224/sbp.2006.34.9.1161

Di Fabio, A., \& Palazzeschi, L. (2009). Emotional intelligence, personality traits and career decision difficulties. International Journal for Educational and Vocational Guidance, 9(2), 135-146. doi: 10.1007/s10775-009-9162-3

Di Fabio, A., Palazzeschi, L., \& Bar-On, R. (2012). The role of personality traits, core self-evaluation, and emotional intelligence in career decision-making difficulties. Journal of Employment Counseling, 49(3), 118-129. doi: 10.1002/j.21611920.2012.00012.x

Di Fabio, A., Palazzeschi, L., Levin, N., \& Gati, I. (2015). The role of personality in the career decision-making difficulties of Italian young adults. Journal of Career Assessment, 23(2), 281-293. doi: 10.1177/1069072714535031

Diaz-Morales, J. F., Ferrari, J. R., \& Cohen, J. R. (2008). Indecision and avoidant procrastination: The role of morningnesseveningness and time perspective in chronic delay lifestyles. Journal of General Psychology, 135(3), 228-240. doi: 10.3200/ Genp.135.3.228-240

Doğan, A., Deniz, M. E., Odabas, H., Özyeşil, Z., \& Özgirgin, N. (2012). Job and life satisfaction of the medical staff in rehabilitation centers. Turkish Journal of Physical Medicine and Rehabilitation, 58, 16-21.

Doğan, H., \& Bacanli, F. (2012). The effect of a career decisionmaking group guidance program on career decision-making difficulties. Energy Education Science and Technology Part B: Social and Educational Studies, 1, 912-916.

Gadassi, R., Gati, I., \& Wagman-Rolnick, H. (2013). The Adaptability of Career Decision-Making Profiles: Associations With Self-Efficacy, Emotional Difficulties, and Decision Status. Journal of Career Development, 40(6), 490-507. doi: 10.1177/0894845312470027 
Gadassi, R., Waser, A., \& Gati, I. (2015). Gender Differences in the Association of Depression With Career Indecisiveness, Career-Decision Status, and Career-Preference Crystallization. Journal of Counseling Psychology, 62(4), 632-641. doi: 10.1037/ cou0000113

Gati, I., \& Amir, T. (2010). Applying a systemic procedure to locate career decision-making difficulties. Career Development Quarterly, 58(4), 301-320. doi 10.1002/j.2161-0045.2010. tb00180.x

Gati, I., \& Asher, I. (2001). Prescreening, in-depth exploration, and choice: From decision theory to career counseling practice. Career Development Quarterly, 50(2), 140-157. doi: 10.1002/ j.2161-0045.2001.tb00979.x

Gati, I., Asulin-Peretz, L., \& Fisher, A. (2012). Emotional and personality-related career decision-making difficulties: A 3-year follow-up. Counseling Psychologist, 40(1), 6-27. doi: 10.1177/0011000011398726

Gati, I., Gadassi, R., Saka, N., Hadadi, Y., Ansenberg, N., Friedmann, R., \& Asulin-Peretz, L. (2011). Emotional and personality-related aspects of career decision-making difficulties: Facets of career indecisiveness. Journal of Career Assessment, 19(1), 3-20. doi: 10.1177/1069072710382525

Gati, I., Krausz, M., \& Osipow, S. H. (1996). A taxonomy of difficulties in career decision making. Journal of Counseling Psychology, 43(4), 510-526. doi: 10.1037//0022-0167.43.4.510

Gati, I., Osipow, S. H., Krausz, M., \& Saka, N. (2000). Validity of the career decision-making difficulties questionnaire: Counselee versus career counselor perceptions. Journal of Vocational Behavior, 56(1), 99-113. doi: 10.1006/jvbe.1999.1710

Gati, I., \& Saka, N. (2001a). High school students' careerrelated decision-making difficulties. Journal of Counseling and Development, 79(3), 331-340. doi: 10.1002/j.1556-6676.2001. tb01978.x

Gati, I., \& Saka, N. (2001b). Internet-based versus paperand-pencil assessment: Measuring career decision-making difficulties. Journal of Career Assessment, 9(4), 397-416. doi: 10.1177/106907270100900406

Germeijs, V., Verschueren, K., \& Soenens, B. (2006). Indecisiveness and high school students' career decision-making process: Longitudinal associations and the mediational role of anxiety. Journal of Counseling Psychology, 53(4), 397-410. doi: 10.1037/0022-0169.53.4.397

Gulec, M., Selvi, Y., Boysan, M., Aydin, A., Besiroglu, L., \& Agargun, M. Y. (2011). Ongoing or re-emerging subjective insomnia symptoms after full/partial remission or recovery of major depressive disorder mainly with the selective serotonin reuptake inhibitors and risk of relapse or recurrence: A 52-week followup study. Journal of Affective Disorders, 134(1-3), 257-265. doi: 10.1016/j.jad.2011.05.056

Hamamcı, Z., \& Çoban, A. E. . (2007). Mesleki olgunluk ve mesleki kararsızı̆̆ın akılcı olmayan inançlarla ilişkisi. Türk Psikolojik Danışma ve Rehberlik Dergisi, 3(27), 31-42.

Harada, T., Morikuni, M., Yoshii, S., Yamashita, Y., \& Takeuchi, H. (2002). Usage of mobile phone in the evening or at night makes Japanese students evening-typed and night sleep uncomfortable. Sleep and Hypnosis, 4(3), 149-153.

Harrison, Y., \& Horne, J. A. (2000). The impact of sleep deprivation on decision making: A review. Journal of Experimental Psychology-Applied, 6(3), 236-249. doi: 10.1037//1076898X.6.3.236
Hirschi, A., \& Laege, D. (2007). The relation of secondary students' career-choice readiness to a six-phase model of career decision making. Journal of Career Development, 34(2), 164-191. doi: 10.1177/0894845307307473

Horne, J. A., \& Ostberg, O. (1976). A self-assessment questionnaire to determine morningness-eveningness in human circadian rhythms. International Journal of Chronobiology, 4(2), 97-110.

Jamali, Y., Araqi, V., \& Kalantarkousheh, S. M. (2015). Function of dysfunctional career thoughts, procrastination and career indecision among Allameh Tabatab'i University Students. European Online Journal of Natural and Social Sciences, 4(1), 57-65.

Kağan, M. (2011). Frost Çok Boyutlu Mükemmeliyetçilik Ölçeği'nin Türkçe formunun psikometrik özellikleri. Anadolu Psikiyatri Dergisi, 12(3), 192-197.

Kayri, M., \& Boysan, M. (2008). Assesment of relation between cognitive vulnerability and depression's level by using classification and regression tree analysis. Hacettepe Universitesi Egitim Fakultesi Dergisi-Hacettepe University Journal of Education(34), 168-177.

Kelly, K. R., \& Lee, W. C. (2002). Mapping the domain of career decision problems. Journal of Vocational Behavior, 61(2), 302326. doi: 10.1006/jvbe.2001.1858

Kelly, K. R., \& Shin, Y. J. (2009). Relation of neuroticism and negative career thoughts and feelings to lack of information Journal of Career Assessment, 17(2), 201-213. doi: 10.1177/1069072708329029

Kesici, Ş., Hamarta, E., \& Arslan, C. (2008). Prediction of elementary

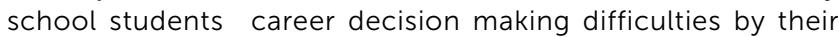
parental attitudes and guidance needs. Elementary Education Online, 7(2), 361-367.

Killgore, W. D. S., Balkin, T. J., \& Wesensten, N. J. (2006). Impaired decision making following $49 \mathrm{~h}$ of sleep deprivation. Journal of Sleep Research, 15(1), 7-13. doi: 10.1111/j.1365-2869.2006.00487.x Kim, S. J., Lee, Y. J., Kim, H., Cho, I. H., Lee, J. Y., \& Cho, S. J. (2010). Age as a moderator of the association between depressive symptoms and morningness-eveningness. Journal of Psychosomatic Research, 68(2), 159-164. doi: 10.1016/j. jpsychores.2009.06.010

Kleiman, T., \& Gati, I. (2004). Challenges of Internet-based assessment: Measuring career decision-making difficulties. Measurement and Evaluation in Counseling and Development, 37(1), 41-55.

Kleiman, T., Gati, I., Peterson, G., Sampson, J., Reardon, R., \& Lenz, J. (2004). Dysfunctional thinking and difficulties in career decision making. Journal of Career Assessment, 12(3), 312-331. doi: $10.1177 / 1069072704266673$

Koumoundourou, G., Tsaousis, I., \& Kounenou, K. (2011). Parental influences on Greek adolescents' career decisionmaking difficulties: The mediating role of core selfevaluations. Journal of Career Assessment, 19(2), 165-182. doi: 10.1177/1069072710385547

Lancaster, B. F., Rudolph, C. E., Perkins, T. S., \& Patten, T. G. (1999). The reliability and validity of the career decision difficulties questionnaire. Journal of Career Assessment, 7(4), 393-413. doi: 10.1177/106907279900700405

Landine, J. R. . (2013). The relationship between vocational selfconcept, ego-identity development, and vocational decisionmaking. The Canadian Journal of Career Development, 12(2), 5-18. 
Lenz, J. G., Peterson, G. W., Reardon, R. C., \& Saunders, D. (2010). Connecting career and mental health counseling: Integrating theory and practice. VISTAS 2010.

Leung, S. A., Hou, Z. J., Gati, I., \& Li, X. X. (2011). Effects of parental expectations and cultural-values orientation on career decision-making difficulties of Chinese University students. Journal of Vocational Behavior, 78(1), 11-20. doi: 10.1016/j. jvb.2010.08.004

Linehan, M. M. (2014). DBT® skills training manual (Second Edition ed.). New York, NY: Guilford.

Marcionetti, J. (2014). Factors affecting teenagers' career indecision in southern Switzerland. Procedia-Social and Behavioral Sciences, 112, 158-166.

Martincin, K. M., \& Stead, G. B. (2015). Five-factor model and difficulties in career decision making: A metaanalysis. Journal of Career Assessment, 23(1), 3-19. doi: 10.1177/1069072714523081

Mau, W. C. (2001). Assessing career decision-making difficulties: A cross-cultural study. Journal of Career Assessment, 9(4), 353-364. doi: 10.1177/106907270100900403

Merikanto, I., Lahti, T., Kronholm, E., Peltonen, M., Laatikainen, T., Vartiainen, E., . . Partonen, T. (2013). Evening types are prone to depression. Chronobiology International, 30(5), 719-725. doi: 10.3109/07420528.2013.784770

Morgan, T., \& Ness, D. (2003). Career decision making difficulties of first year students. The Canadian Journal of Career Development, 2(1), 33-37.

Muller, M. J., Kundermann, B., \& Cabanel, N. (2016). Eveningness and poor sleep quality independently contribute to self-reported depression severity in psychiatric inpatients with affective disorder. Nordic Journal of Psychiatry, 70(5), 329-334. doi: 10.3109/08039488.2015.1112832

Natale, V., \& Cicogna, P. (2002). Morningness-eveningness dimension: is it really a continuum? Personality and Individual Differences, 32(5), 809-816. doi: 10.1016/S01918869(01)00085-X

Nazli, S. (2007). Career development in primary school children. Career Development International, 12(5), 446-462.

Osipow, S. H., \& Gati, I. (1998). Construct and concurrent validity of the career decision-making difficulties questionnaire. Journal of Career Assessment, 6(3), 347-364. doi: 10.1177/106907279800600305

Oztemel, K. (2013). Testing the validity of the Emotional and Personality-Related Career Decision-Making Difficulties Questionnaire in Turkish Culture. Journal of Career Development, 40(5), 390-407. doi: 10.1177/0894845312468060

Oztemel, K. (2014). Career indecisiveness of Turkish high school students: Associations with personality characteristics. Journal of Career Assessment, 22(4), 666-681. doi: $10.1177 / 1069072713515630$

Öztemel, K. (2012). Kariyer kararsızlığı ile mesleki karar verme öz yetkinlik ve kontrol odağı arasındaki ilişkiler. Gazi Üniversitesi Gazi Eğitim Fakültesi Dergisi, 32(2), 459-477.

Öztemel, K. (2013). Lise öğrencilerinin kariyer karar verme güçlüklerinin yordayıcıları olarak algılanan sosyal destek ve cinsiyet. Türk Eğitim Bilimleri Dergisi, 11(3), 241-257.

Perlis, M. L., Jungquist, C., Smith, M. T., \& Posner, D. (2008). Cognitive behavioral treatment of insomnia: A session-by-session guide New York, NY: Springer.
Perţe, A. . (2013). On career indecision: Testing the relationship between irrational thinking, self-esteem, trait anxiety and career decision-making self-efficacy. Romanian Journal of School Psychology, 11, 115-125.

Peterson, G. W., Sampson Jr, J. P., Lenz, J. G., \& Reardon, R. C. (2002). A cognitive information processing approach to career problem solving and decision making. In D. Brown (Ed.), Career Choice and Development (4th Edition ed., pp. 312-369). San Francisco, CA: Jossey-Bass.

Restubog, S. L. D., Fiorentino, A. R., \& Garcia, P. R. J. M. (2010). The mediating roles of career self-efficacy and career decidedness in the relationship between contextual support and persistence. Journal of Vocational Behavior, 77(2), 186-195. doi: 10.1016/j. jvb.2010.06.005

Rottinghaus, P. J., Jenkins, N., \& Jantzer, A. M. (2009). Relation of depression and affectivity to career decision status and selfefficacy in college students. Journal of Career Assessment, 17(3), 271-285. doi: 10.1177/1069072708330463

Saka, N., \& Gati, I. (2007). Emotional and personality-related aspects of persistent career decision-making difficulties. Journal of Vocational Behavior, 71(3), 340-358. doi: 10.1016/j. jvb.2007.08.003

Saka, N., Gati, I., \& Kelly, K. R. (2008). Emotional and personality-related aspects of career-decision-making difficulties. Journal of Career Assessment, 16(4), 403-424. doi: 10.1177/1069072708318900

Sateia, M. J., \& Buysse, D. (2010). Insomnia: Diagnosis and Treatment CRC Press.

Selvi, Y., Aydin, A., Boysan, M., Atli, A., Agargun, M. Y., \& Besiroglu, L. (2010). Associations between chronotype, sleep quality, suicidality, and depressive symptoms in patients with major depression and healthy controls. Chronobiology International, 27(9-10), 18131828. doi: $10.3109 / 07420528.2010 .516380$

Shin, Y. J., \& Kelly, K. R. (2015). Resilience and decisionmaking strategies as predictors of career decision difficulties. Career Development Quarterly, 63(4), 291-305. doi: 10.1002/ cdq.12029

Sidiropoulou-Dimakakou, D., Mylonas, K., Argyropoulou, K., \& Tampouri, S. (2012). Career decision-making difficulties, dysfunctional thinking and generalized self-efficacy of university students in Greece. World Journal of Education, 2(1), 117-130.

Sovet, L., Tak, J., \& Jung, S. (2015). Validation of the Career Decision-Making Difficulties Questionnaire among Korean college students. Journal of Career Assessment, 23(4), 661-676. doi: $10.1177 / 1069072714553556$

Tagay, Ö. (2014). Career decision-making diffuculties in Turkey and the USA. International Journal of Recent Advances in Multidisciplinary Research, 2(2), 232-239.

Taillard, J., Philip, P., \& Bioulac, B. (1999). Morningness/eveningness and the need for sleep. Journal of Sleep Research, 8(4), 291-295. doi: 10.1046/j.1365-2869.1999.00176.x

Tavernier, R., \& Willoughby, T. (2014). Are all evening-types doomed? Latent class analyses of perceived morningnesseveningness, sleep and psychosocial functioning among emerging adults. Chronobiology International, 31(2), 232-242. doi: $10.3109 / 07420528.2013 .843541$

Tien, H. L. S. (2005). The validation of the career decisionmaking difficulties scale in a Chinese culture. Journal of Career Assessment, 13(1), 114-127. doi: 10.1177/1069072704270327 
Tonetti, L. (2007). Validity of the Morningness-Eveningness Questionnaire for adolescents (MEQ-A). Sleep and Hypnosis, 9(2), 47-51.

Tonetti, L., Fabbri, M., Boreggiani, M., Guastella, P., Martoni, M., Herrera, N. R., \& Natale, V. (2016). Circadian preference and decision-making styles. Biological Rhythm Research, 47(4), 573581. doi: 10.1080/09291016.2016.1167312

Tzischinsky, O., \& Shochat, T. (2011). Eveningness, Sleep Patterns, Daytime Functioning, and Quality of Life in Israeli Adolescents. Chronobiology International, 28(4), 338-343. doi: 10.3109/07420528.2011.560698

Walker, J. V., \& Peterson, G. W. (2012). Career thoughts, indecision, and depression: Implications for mental health assessment in career counseling. Journal of Career Assessment, 20(4), 497-506. doi: $10.1177 / 1069072712450010$
Yeşilyaprak, B. (2012). Mesleki rehberlik ve kariyer danışmanlığında paradigma değişimi ve Türkiye açısından sonuçlar: Geçmişten geleceğe yönelik bir değerlendirme. Kuram ve Uygulamada Eğitim Bilimleri, 12(1), 97-118.

Yeşilyaprak, B., \& Boysan, M. . (2015). Latent class analysis of job and life satisfaction among school counselors: a national survey Journal of Happiness Studies, 16(1), 1-15. doi: 0.1007/s10902013-9491-2

Zhou, D. Y., \& Santos, A. (2007). Career decision-making difficulties of British and Chinese international university students. British Journal of Guidance \& Counselling, 35(2), 219-235. doi: 10.1080/03069880701256684 